Предраг Лажетић

Музеј југословенског ратног ваздухопловства

Београд

predraglazetic@gmail.com

https://doi.org/10.18485/ai_godine_ww1.2019.ch15

94(4)"1914/1918"

355.48(4)"1914/1918"

\title{
ВРЕДНОВАЮЕ ТРАДИЦИЈА ПРВОГ СВЕТСКОГ РАТА У ЗБИРКАМА И НА ПОСТАВКАМА ВОЈНОГ МУЗЕЈА У БЕОГРАДУ 1918-2018.
}

Anстракт: У чланку се приказује однос власти и музејских радника према Првом светском рату кроз однос према прикупљању музејских предмета, њиховом вредновању, излагању на изложбама Војног музеја и на његовима различитим сталним поставкама, од дана са Солунског фронта, времена Краљевине Југославије, првих послератних година после Другог светског рата и времена социјалистичке Југославије до времена распада СФРј деведесетих година XX века.

Кључне речи: Војни музеј, Први светски рат , музејски предмети, музејска поставка, изложбе, традиција, Други светски рат, вредновање, збирке.

Светски рат, чији се крај почетком 1917. године још није назирао, поколебао је темеље људске култуpe, порушио основе мирног културног живота у свету. Догађаји који су преживљавани били су велики а последице огромне, па је отуда на свим странама дошло до појединачних или колективних тежњи да се за историју овог рата сакупи и сачува од заборава све што се на њега односи, све што би допринело да се овај догађај, јединствен у светској историји, „представи потомству 
што верније и рељефније, како по својим узроцима, тако и по вођењу рата, трајању и последицама које ће собом донети“.

Већ на почетку рата код зараћених страна јавила се иста мисао да се на једно место прикупља документација о рату и свему ономе што га је пратило и што је имало значај за његово свеобухватније сагледавање. Скоро у исто време у Француској, Енглеској, Немачкој појединци и институције, а у Италији поједини градови, спонтано су долазили на идеју о оснивању ратног музеја.

И у српској војсци на Солунском фронту, почетком 1917, појавила се идеја о прикупљању историјског материјала ради образовања новог српског Војног музеја. Командант 1. батаљона 8. пука, потпуковник Радомир Елезовић, који је у првим данима рата 1914. године бранио Београдску тврђаву и музеј у њој, писао је марта 1917. године, са прве линије фронта, да „раније мали и незнани, постаћемо познати и поштовани од савезника као и од непријатеља. Па ће после рата силни странци нагрнути у некада малу земљу великих јунака и оно што ће странце највише интересовати биће све што је имало везе са нашим ратовима“. ${ }^{2}$

Министарство војно издало је 26. јула 1917. године наређење Врховној команди, у којем се подсећало на Војни музеј који је постојао у отаџбини и који је и поред свих покушаја да се спасе остао непријатељу у рукама, да се створи нова збирка. ${ }^{3}$

Потреба да се прикупљају предмети за нову збирку Војног музеја образлагана је потребом да се сви савре-

1 Српске новине, бр. 3, 6. 1. 1918, Крф.

2 Војислав Вуковић, Војни музеј, Велики војни календар, 1936, стр. 157.

3 Службени војни лист, бр. 19, 5. август 1917, Солун. 
меници, али и покољења, опомињу на натчовечанске напоре и жртве које је поднео српски народ и његова војска „бранећи стопу по стопу своје драге отаџбине, губећи је на начин каквоме у истирији нема равна и повраћајући је беспримерним пожртвовањем у заједници са савезницима“. Патња и ужаси рата и „сва величина и силина душе“ народа и херојство српске војске, поред тога што је требало да се опишу у „масама књига и опева у песмама“, требало је и да се овековече прикупљањем предмета за збирке Војног музеја.

Према наређењу министра војног генерала Божидара Терзића, Војни музеј није требало да буде само збирка оружја, муниције, застава и другог, која би као таква била непотпуна, већ је требало прикупити апсолутно све што би могло представити изглед војске у рату, како је била наоружана и одевена, како је била снабдевена санитетским и инжињерским потрепштинама. Требало је прикупити све оно што је створила војничка рука да себи олакша исхрану, становање, да изгради заклоне од непријатеља, да створи колико- толико разоноде песмом уз импровизоване музичке инструменте.

Задатак да прикупљају предмете добиле су све команде, јединице и установе на фронту и у позадини, на Крфу, у Африци и уопште у иностранству.

Наређено је прикупљање фотографија разних личности, штабова, трупа, болница, логора, положаја, ровова, зграда, вароши, села, разних епизода из војничког живота у борби, на маршу, на одмору, на фронту и у позадини. Временски је то требало да покрије читав период од почетка рата, преко повлачења кроз Црну Гору и Албанију, боравка на Јадрану, Крфу, Бизерти, Солунском фронту, али и у свим будућим ситуацијама.

Поред фотографија, Војни музеј требало је обогатити и цртежима и панорамским снимцима свих сектора 
и положаја на којима су вођене борбе и бојеви у току рата. Ове послове углавном су обављали ратни сликари и фотографи који су били у формацијском саставу Српске војске, али и бројни фотографи аматери. Допринос верном приказу ратних напора Србије и њене војске дали су и фотографи дописници.

У Првом светском рату учествовало је више од 40 ратних сликара којима је Врховна команда Српске војске поверила веома значајан задатак - да на основу израђених скица које су пратиле најзначајније моменте борбе израде слике, које је трбало да понуде на откуп првенствено Министарству војном. ${ }^{4}$

Неколико дана након пробоја Солунског фронта министар војни обновио је наређење, 19. септембра 1918. године, а Војни музеј упутио позив за прикупљање музејских предмета. Схватање вишедимензионалности рата и његовог значаја налагало је да се у позиву инсистира на прикупљању веома широког спектра предмета. Обнављени музеј је требало да има већи значај за потомке него што су га имали савезнички ратни музеји, јер је како је стајало у наређењу и позиву, српски народ у Великом рату дао све што је могао дати, а Сpбија се „у њему највише жртвовала за част и достојанство, јер је у њему изгубила готово све“. Тражено је да се будућим генерацијама остави што потпунија успомена на „најкрвавију, најславнију и најважнију епоху“ српске историје. ${ }^{5}$

Планови о обнављању Војног музеја, иако наређени, остали су само жеља малог броја ентузијаста. Ос-

4 После завршетка Првог светског рата, са изложби ратних сликара Врховне команде, Министарство војске и морнарице Краљевине СХС откупило је бројне слике, које је 1935. године уступило обновљеном Војном музеју.

5 Архив ВИИ, П-3, К-408, Ф-9, док-9/21. 
лобођење Србије и улазак српске војске у Београд, 1. новембра 1918, нису донели ништа боље услове за обнављање и развој Војног музеја. Ослободиоце је дочекао народ на улицама, заставе, цвеће, осмеси, песме, али и разрушене или руиниране зграде, а опљачкане музејске збирке пренете су у музеје Пеште, Берлина и Беча.

И поред недостатка зграде и нерегулисаног статуса Војног музеја, двадесетих година ипак је настављен рад на прикупљању предмета. Предмети су слати су директно или преко Транзитног слагалишта Министарства војске и морнарице у Војнотехнички завод (Артиљеријско-технички завод) у Крагујевцу чији је управник био задужен да устроји посебан инвентар за Војни музеј и да у њега уведе све интересантне предмете који имају музејску вредност, те да их уреди за излагање. ${ }^{6}$

Тек шеснаест година после завршетка Великог рата створена је могућност да се јавности прикажу прикупљени предмети. Наиме тек је потписивањем Уредбе о образовању Војног музеја у Београду, 18. априла 1934. године, краљ Александар I Карађорђевић означио нови почетак овог музеја у новоствореној држави и могућност да тиме допринесе чувању војничких традиција у војсци и народу. ${ }^{7}$

Међутим, смрт краља Александра I Карађорђевића, 9. октобра 1934, успорила је конституисање и почетак рада Војног музеја, који је ипак добијањем зграде, одређивањем саветодавног одбора 11. фебруара 1935.

6 Архива Војног музеја, Књига I инвентара за 1935/36. годину, Књига I инвентара за 1936-1941. годину; Инвентарска књига библиотеке Војног музеја; Записник одржаних седница саветодавног одбора Војног музеја за 1935, 1936, 1937, 1938 закључно са мајем 1939. године.

7 Службени војни лист, бр.16, 27. 4. 1934. Уредба Ђ.Бр. 5789 од 18. 4. 1934. 
године и одржавањем прве седнице одбора, 14. марта 1935. године почео рад.

Правилник о уређењу Војног музеја захтевао је да се у музејској поставци оформе одељења: 'народне династије Карађорђевића”, “осталих народних династија и владара", 'народних војничких вођа и знаменитијих војника", 'борби и ратова до 1912. године", 'ратова од 1912-1918. године”, “историјског развоја наооружања” и "опште" одељење.

У “Одељењу ратова од 1912-1918. године” требало је да се изложе предмети из свих ратова из овог периода, од почетка мобилизације па до дана демобилизације, свих учесника у ратним дејствима. Планирано “одељење историјског развоја наооружања" требало је да прикаже развој наоружања српске војске, од њеног установљења, као и наоружање савезничких и непријатељских војски. Сви предмети од значаја за српску војску, њену историју, спрему, исхрану, технику и друго који нису ушли у друга одељења требало је да уђу у "опште одељење".

Месец дана након конституисања Савета Војног музеја и избора Оружног одбора, од техничког слагалишта Војнотехничког завода у Крагујевцу примљено је током 1935. године преко 1.200 примерака различитог оружја, оруђа, униформи, штамбиља, ознака, војничких рукотворина, чаура и другог. Исте године Војни музеј је из Крагујевца примио на стотине фотографија, бројне књиге, календаре, албуме, географске карте и атласе. $^{8}$

8 Архива Војног музеја, Књига I инвентара за 1935/36. годину, Књига I инвентара за 1936-1941. годину; Инвентарска књига библиотеке Војног музеја; Записник одржаних седница саветодавног одбора Војног музеја за 1935, 1936, 1937, 1938 закључно са мајем 1939. године. 
Музејске збирке Војног музеја обогатило је Министарство војске и морнарице пошто му је предало портрете краља Петра I Карађорђевића, војводе Живојина Мишића, војводе Степе Степановића, војводе Петра Бојовића, генерала Милоша Васића и друге. Од Министарства војске су добијене 1935. године и слике: "Острвски и Чегарски висови", "Пораз Бугара и Немаца на коти 1212, 1916. године", "Легенда о повлачењу српске војске за Драч и Валону 1915. године", "Скочивир", “Острво Крф", 'Грунишки вис" и "Кајмакчалан” (рад сликара Васе Ешкићевића), слике "Из борбе у борбу", "Соко планина" и "Чегар", које је урадио сликар Михаило Миловановић и слика "Пробој Солунског фронта", рад сликара Вељка Станојевића, које су откупљене двадесетих година. Књижница генералштабног одељења Министарства војске и морнарице предала је Музеју поред књига Велики рат Србије и других књига, и 67 колорисаних слика и бројне фотографије. ${ }^{9}$

Из ратне архиве Министарства војске и морнарице Војни музеј је добио 103 Громанове фотографије које су у ову архиву ушле 1924. године, 203 фотографије официра Добровољачког корпуса у Русији, 538 фотографија врховног команданта регента Александра I Карађорђевића, официра, подофицира, каплара и редова из времена од 1914. до 1920. године. Из ратне архиве предате су Војном музеју и фотографије које су, 1934. године, откупљене од ратног фотографа Риста Шуковића и од Васе Радуловића, фотографа из Пећи. ${ }^{10}$

9 Архива Војног музеја, Књига I инвентара за 1935/36. годину, Књига I инвентара за 1936-1941. годину; Инвентарска књига библиотеке Војног музеја; Записник одржаних седница саветодавног одбора Војног музеја за 1935, 1936, 1937, 1938 закључно са мајем 1939. године.

10 Фотоархива Војног музеја, Пописник ратних и послератних фотографија у ратној архиви. 
Своје фондове Војни музеј је у великој мери попунио даровима које је добијао од појединаца и установа из земље и иностранства. У периоду од 1935. године па до почетка рата 1941. године прикупљено је даровима 3.052 предмета.

Породице знаменитих српских војсковођа и генерала даривале су Војни музеј. Тако су у музеј доспели предмети војводе Степе Степановића, генерала Милоша Васића, Павла Јуришића-Штурма, Михаила Живковића, Божидара Терзића. Музеј су бројним предметима даровали генерали Иван С. Павловић, Душан Стефановић, Стеван Пешић, Душан Исаковић, Жарко Рувидић, Петар Арачић, Љубомир Максимовић, Светислав Симовић, Јован Викторовић, Петар Пешић, Ђорђе Протић, Никола Дероко, Војислав Томић, Александар Крупежевић, Стеван Бошковић и други.

Значајан број музејских предмета Војном музеју даровале су државе савезнице Краљевине Србије у Првом светском рату ради њиховог излагања у музеју, али и државе које су јој биле противнице у том рату. Музеј су даровали Краљевина Италија, Краљевина Белгија, војска Француске Републике, Краљевина Румунија, Република Чехословачка, Бугарски Војни музеј, мађарски Војни музеј и архив и Краљевина Грчка.

Да би се комплетирале музејске збирке и уредила стална изложбена поставка Војног музеја, извршени су значајни откупи уметничких дела. Нарочити значај уметнички одбор Војног музеја давао је делима која су нудили ратни сликари, ценећи их јер су рађене у ратном вихору или по импресијама њихових аутора стечених у рату.

Што преузимањем из установа и јединица Војске Краљевине Југославије, што поклонима и откупима у Војном музеју, створена је значајна збирка фотогра- 
фија из ратова вођених на простору Балкана од 1912. до 1918. године, које су израдили ратни сликари, фотографи аматери и дописници фотографи у српској војсци.

Три године после уредбе краља Александра I Карађорђевића о оснивању Војног музеја и две године после његовог конституисања, Музеј је свечано отворен 20. априла 1937. године. Поред кнеза Павла Карађорђевића, отварању су присуствовали краљевски намесници, председник владе Милан Стојадиновић, патријарх Варнава, бројни министри, представници двора, генерали, изасланици свих београдских команди и установа, страни амбасадори и војни аташеи.

До свечаног отварања било је завршено 'Одељење блаженопочившег витешког краља Александра I Ујединитеља" и "Одељење светског рата 1914-1918. године", оба смештена у згради бр.1 Војног музеја.

За одељење посвећено краљу Александру I Карађорђевићу био је одвојен највећи простор у музеју. Предмети који су припадали краљу Александру, бројни његови портрети и скулптуре али у аутомобил у коме је убијен у Марсеју били су у птиземљу док је на спрату било смештено одељење ратова од 1912. до 1918. године. У холу на спрату посетиоце су дочекивали портрети и скулптуре краља Петра I Карађорђевића и краља Александра I Карађорђевића, те српских војвода Радомира Путника, Живојина Мишића, Степе Степановића и Петра Бојовића. Бројни предмети који су се налазили у овом одељењу (оружје, опрема, униформе, слике, скулптуре, фотографије, макете и друго) требали су посетиоцима да прикажу све ратне догађаје од дана мобилизације до дана демобилизације, како српске војске тако и савезничких и противничких војски.

У одељењу посвећеном повлачењу српске војске преко Албаније, поред рељефа, на зидовима су биле 
изложене слике: 'Повлачење преко Косова 1915”, ‘Кроз Албанију”, “Две грабљивице” рад сликара Богосава Војновића Пеликана, слика 'Краљ Петар четири вола" и многи други цртежи и скулптуре који су забележили најтеже тренутке српске војске, њена страдања, али и храброст и издржљивост.

Посебно место у музејској поставци добила је Француска савезница Србије из Првог светског рата и најважнији полератни ослонац у спољној политици Краљевине Југославије. Значајан простор у поставци добило је Румунско одељење које је завршено крајем 1936. године, пошто је румунско посланство у Београду 29. септембра 1936. даровало предмете Војном музеју. Свакако да је на овај простор много већи значај од улоге Румуније у Првом светском рату имало то што је Краљевина Југославија са њом била од 1920. године у Малој антанти и што се Краљ Александар оженио 1922. године кћерком румунског краља Фердинанда принцезом Маријом.

Иако није била савезница у Првом светском рату велики простор у поставци је добила Чехословачка. На то је утицало чланство Чехословачке у Малој антанти али и ослањање војске Краљевине Југославије на набавку наоружања произведеног у чешким фабрикама и на лиценце које је добијала за производњу оружја у Војнотехничком заводу у Крагујевцу. ${ }^{11}$

У једној витрини било је изложено заробљено немачко оружје и шлемови. Изложена су средства везе и бројне војничке рукотворине са Солунског фронта.

11 Архива Војног музеја, Списак дарова Војном музеју; Записник одржаних седница саветодавног одбора Војног музеја за 1935, 1936, 1937, 1938 закључно са мајем 1939. године, 7. седница од 17. децембра 1936. 
У парку испред музеја налазиле су се стражара и продавница улазница. Кров продавнице био је у облику француског шлема с. Адријан, које је од Солунског фронта носила српска војска, а после рата и војска Краљевине Југославије. У овој продавници је до јануара 1941. године продато више од милион и двеста хиљада улазница (око 300.000 годишње).

Војни музеј развијао се тако брзо да су зграде којима је располагао постале недовољне за смештај и излагање до тада прикупљених музејских предмета, а о даљем развоју није се могло ни размишљати. Зато је 1938. године израђен програм за нову зграду. Планирана је изградња зграде у Горњем граду Београдске тврђаве чија је укупна површина требало да буде више од $6.700 \mathrm{~m} 2$, и која би имала репрезентативно двориште са колонадом, у коме је требало да буду постављени тежи предмети, скулптуре и споменици. Трећина овог простора (око $2.000 \mathrm{~m} 2$ ) на првом спрату поалирана је за одељење балканских ратова (око $300 \mathrm{~m} 2$ ) и за одељење Великог рата 1914-1918. (1.700 m2).

Сликар Михаило Миловановић упутио је министру војске и морнарице генералу Љубомиру Марићу и управнику Војног музеја предлог за израду панорамских слика у Горњем граду Београдске тврђаве. До детаља је разрадио своју идеју, зачету још на Солунском фронту, за израду панорамских слика великих битака српске војске у ратовима 1912. до 1918. године (Кумановску битка, Церска битка, Колубарска битка, Албанска трагедија и Кајмакчалан). Према замисли Миловановића, свака од ових слика захтевала би посебно одељење, чија би унутрашњост морала да буде потпуно округла и не би на зиду имала са стране ни врата ни прозоре. Унутрашњост овог простора, односно тло зграде, од трибине где би се налазили посетиоци до округлог зида на коме би била 
израђена слика, требало би да буде покривено камењем и земљом који би се донели са терена на којем се водила битка. На том простору требало је да се израде оригинални ровови, топовски заклони са стварним топовима, митраљезима, војници начињени и намештени у разним покретима и положајима, са оружјем и тачно онако како је то било за време борбе, рањени и мртви војници, овде-онде делови војничке опреме, огорели пањеви и згаришта где су ложене ватре и друго. ${ }^{12}$

Унутрашњост зграде, како ју је предлагао Миловановић, без врата и прозора са сликом без краја и почетка и са распоредом и прелазом из стварних објеката на тлу ка сликама на зиду, требало је да омогући утисак да се не гледа у слику већ да се доживи једна стварна битка на терену.

Међутим, почетак Другог светског рата септембра 1939. године и агресија сила Осовине на Краљевину Југославију 6. априла 1941. године, окупациони режим и друго за дуже време су одложили питање решавања уређења Горњег и Доњег града Београдске тврђаве и Калемегдана, па и простора за Војни музеј. Као и у претходном рату из зграде музеја претрпеле су знатна оштећења док су бројни музејски предмети нестали. Нестале су скоро комплетне збирке династија Карађорђевић, Обреновић, Петровић, руске регалије и многи други драгоцени предмети.

Војни музеј је ослобођење Београда града дочекао у ранама. Кратери од граната и ровови у парку са гомилама шута, испревртаним и оштећеним музејским предметима давало је утисак фронта а не парка.

12 Архива Војног музеја, Записник одржаних седница саветодавног одбора Војног музеја за 1935, 1936, 1937, 1938, закључно са мајем 1939. године, књига I. Записник 27. седнице од 7. децембра 1938; Ђорђе Пилчевић, Академски сликар Михаило Миловановић: живот и дело: 1879 -1941, Ужице, 1998. стр. 132-134. 
Да би се могло приступити организовању, пословању и уређењу Војног музеја у "духу народноослободилачког покрета" основан је фебруара 1945. године нови Саветодавни одбор и израђен Упут за прикупљање предмета, који је требао доставити свим војним јединицама и народноослободилачким одборима. Упут је у великој мери понављао текст из Наређења о прикупљању предмета Министарства војске Краљевине Србије у Солуну 1917. године. ${ }^{13}$

Од Врховног штаба тражено је да се изда одобрење за организацију сабирања униформи, обуће, оруђа и оружја оштећених и неупотребљивих за даље коришћење и њихово допремање у Војни музеј. Тражено је, такође, да се сва ратна опрема истакнутих војсковођа и ратника из народноослободилачке борбе да Војном музеју како би се спровела замисао о раду Војног музеја у „духу наше НОБ-е“.

Управник Војног музеја указивао је на неопходност да се командантима са фронта скрене пажња да постоји Војни музеј и да би све ратне трофеје, успомене на поједине борбе, једном речју све што им се учини значајније и вредније, требало да прикупљају и згодном приликом, било непосредно било посредно преко надлежних команди, доставе Војном музеју. Тражено је да се предузму потребне мере за сабирање ратних трофеја НОВ „да би се илустровала слава, снага и величина народне војске“, ратних трофеја „фашистичких окупаторских војски да би се видела огромна фашистичка снага, коју је савладала наша војска уз помоћ братске Црвене армије“, те ратних трофеја „савезничке братске Црвене армије који би се чували уз ратне трофеје НОВ

13 Архив Србије, Г-183, Одлуке АСНОС-а Повереништву просвете, 6р. 435, 6р. 436, бр. 437 од 17. 2. 1945. 
као залога братства и јединства НОВ и славне Црвене армије“. ${ }^{14}$

Неопходност прикупљања предмета аргументована је поновним силним напорима наших народа „да прикупимо нову историјску збирку која ће нас, а нарочито наша покољења опомињати на натчовечанске напоре и жртве које су наши народи и њихова народноослободилачка војска поднели бранећи стопу по стопу своје напаћене отаџбине, губећи је на начин каквог у историји нема равна, а повраћајући је са беспримерним пожртвовањем, истрајношћу и храброшћу са нашим великим савезницима. Све патње и ужаси које смо преживели и све величина и силина душе наших народа и херојство наше војске поред тога што ће бити и у многим књигама описано и у песмама опевани треба учинити да и скупљеним збиркама у Војном музеју да наша покољења и странци што боље схвате ову велику епопеју коју народи Југославије сада преживљавају са својом војском“. 15

Према овом упутству, Војни музеј није требало да буде само збирка оружја, муниције, застава и другог, јер би као таква била непотпуна, већ је тражено да се прикупља апсолутно све што би могло да представља војску у рату, њено наоружање и опрему, њен начин борбе, исхране, снабдевања, њену инжењерију, санитет, ваздухопловство и друго. Тражено је прикупљање свега што је војничка рука створила да би себи олакшала борбу, исхрану, становање или да себи колико-толико дала одушка песмом уз импровизоване музичке инструменте.

14 Архив Србије, Г-183, Писмо В. Вуковића Повереништву просвете АСНОС-а бр. 21 и бр. 22 од 22.02.1945.

15 Архив Србије, Г-183, Управник Војног музеја Председништву АСНОС-а, Повереништву за просвету бр. 47 од 2. 4. 1945. 
Крајем 1950. године дошло је и до реорганизације музеја, а пред запослене је постављен задатак да се преуреди постојећа поставка "на принципима дијалектичког схватања историје” и систематски среде и научно обраде музејски предмети.

Школованим историчарима и музеалцима супротстављени су „партијски кадрови“, за које се сматрало да и без потребног знања својим фанатизмом и „правилним“ ставом могу то да превазиђу. Са њима је у Војном музеју који је требао да води бригу о традицији у војсци превладао дилетантизам, аматеризам, догматизам, идеолошка искључивост, „социјалистички патриотизам“, „партизанско југословенство“ из којих је рационално и критичко мишљење било потиснуто. ${ }^{16}$

Запослени у Музеју од завршетка рата па до почетка педесетих година нису били музеалци. Иако је међу њима било факултетски образованих људи, они нису имали веће музеолошко искуство или знање из историје, које је било и под огромним утицајем идеологије.

Према партијским ставовима традиција је морала да буде марксистички и критички осветљена „на нов начин“, да буде напредна, социјална, разумљива и приступачна широким круговима народа. Критика је оцењивала и дело и аутора, и уколико би један од елемената био доведен у сумњу и под идеолошки знак питања, такво наслеђе је одбацивано као негативно. ${ }^{17}$

Оваква пракса није мимоишла ни Војни музеј. Пошто је Војни музеј располагао са већим бројем слика, а

16 Љубодраг Димић, Историографија под надзором, Прилози историје историограбије, I, Београд, 1996. стр. 201

17 Љубодраг Димић, Агитпроп култура. Агитпроповска фаза културне политике у Србији 1945-1952, Београд 1988; Ђорђе Станковић, Љубодраг Димић, Историографија под надзором, Прилози историје историографије, I, Београд, 1996. стр. 182. 
у вези сређивања материјалног пословања, одређена је, децембра 1951. године, стручна комисија која имала задатак да прегледа слике и утврдити: које су слике уметничке вредности и требало би их продати, које су слике историјске вредности и требало би их задржати за потребе Војног музеја и које би слике требало расходовати пошто немају ни уметничку ни историјску вредност. ${ }^{18}$

Комисија је нажалост била врло експедитивна јер су слике за које је процењено да „данас не представљају никакву уметничку ни историјску вредност" истога дана уништене спаљивањем у присуству чланова комисије, а управнику Музеја је достављен њихов списак, за који је он донео решење о расходовању војне имовине на терет државе и раздужење у инвентарским књигама.

На списку слика "које данас не представљају никакву уметничку вредност” била су и платна Паје Јовановића (портрет краља Александра из доба регентства, репродукције слика "Други устанак Милоша Обреновића" и "Сеоба Срба под Чарнојевићем"); Јована Бијелића (портрет краља Петра I), дела ратних сликара Михаила Миловановића (портрет генерала Војислава Вуковића, управника Војног музеја; портрет генерала Љубомира Марића, министра војске и морнарице 1937. године; портрет команданта Дринске дивизије, пуковника Крсте Смиљанића, са начелником штаба потпуковником Милутином Недићем, на Солунском фронту 1918. године; портрет геодетског пуковника, начелника топографског оделења Стевана Бошковића на Солунском фронту 1918. године, слика "Артиљерија у бури"); Драгомира Глишића (слике "Пад Грунишког виса" и

18 Љубодраг Димић, Агитпроп култура. Агитпроповска фаза културне политике у Србији 1945-1952, Београд 1988; Ђорђе Станковић, Љубодраг Димић, Историограбија под надзором, Прилози историје историографије, I, Београд, 1996. стр. 182. 
"Тепелински вијадукт"), Вељка Станојевића (портрет краља Александра I Карађорђевића); Васе Ешкићевића (слика "Македонски фронт, српска коњица на висовима 1916. године"); Богосава Војновића Пеликана (слика "Плава гробница"), Милоша Голубовића (слика "Крф на земљи спаса"). Међу сликама које су оцењене да су без икакве вредности своје место нашла су и дела руских сликара емиграната.

Спаљене су слике Сергеја Обраскова (портрет кнеза Александра Карађорђевића, портрет краља Петра I са огртачем за венчање, портрет краља Александра I - копија од Скота, портрет руског цара Николе II, портрет генерала Мостића из времена Обреновића, портрет краља Петра II), Валентине Васиљев (портрет руске царице Јекатерине, портрет кнеза Арсена Карађорђевића).

Свој крај на ломачи нашла су и дела Ђорђа Јергића (слика "Милош Обилић"), Адолфа Херинга (портрет "Краљ Александар Обреновић са вилом"), Ухлика (слика главе краља Петра I и краља Александра; портрет краља Александра I; портрет краљице Марије), Крековића (портрет краља Петра I у парадној униформи; портрет краља Петра I; портрет краља Александра I Карађорђевића у генералској униформи; портрет кнегиње Зорке; портрет кнеза Павла у гардијској униформи; портрет краља Петра II) и других. Од 103 спаљене слике, 51 су били портрети личности из династије Карађорђевића (краља Петра I - 15 слика, краља Александра - 14 слика, краља Петра II - 4 слике, кнеза Павла - 5 слика, краљице Марије - 6 слика итд.), 10 слика портрети руских владара и генерала, 8 портрети југословенских генерала и министара војске и морнарице, 4 портрети Обреновића, а двадесетак су биле слике са фронта и пејзажи.

Пошто „не представљају никакву музејску вредност јер су поломљене“, расходовани су 1952. године фигу- 
ра-модел од гипса „Победник“ рад вајара Ђорђа Јовановића, посмртна маска др Арчибалда Рајса од гипса и фигура „Човек на колцу“ од гипса, за коју се може претпоставити да је откупљена 1937. године од вајара Мајзнера под именом "Набијање на колац Коче Капетана". ${ }^{19}$

Комисија музеја је такође „оценила“ да су неки предмети, пошто „не долазе у обзир за излагање а нити за комплетирање збирке из ранијих ратова“, непотребни Војном музеју, а пошто се не могу ни уступити неком другом музеју на коришћење, због тога мора извршити њихова деформација и предаја отпаду. На ова начин је на отпаду завршило двадесет плакета од бронзе са ликовима краља Петра I Карађорђевића, краља Александра I Карађорђевића, кнеза Павла Карађорђевића, краља Петра II Карађорђевића, војводе Степе Степановића и друге које су урадили вајари Рудолф Спиглер из Загреба, Илија Коларевић из Београда, Периша Милић и други. Расходована је биста од бронзе Николе Пашића, посмртна маска од бронзе краља Петра I Карађорђевића, гусле „јаворове са гравираним ликовима свију владара од Људевита до Петра“" и друго. ${ }^{20}$

Почетком 1952. године извршена је адаптација музејских зграда, у којима су, после урађених тематских планова, за кратко време уређена и отворена два одељења. Одељење "Стварања ЈНА", отворено 1. маја 1952. године, обиловало је музејским предметима, фотографијама и документима који су били изложени у 14 просторија зграде број І у којој су до рата била одељења краља Александра I Карађорђевића и „Одељење свет-

19 Архива Војног музеја, Инвентар I за 1936-1941; Реферат и комисијски извештај бр.288 од 22. 2. 1952.

20 Архива Војног музеја, Инвентар I за 1936-1941. годину; Инвентар II за 1951-1952.; Реферат и комисијски извештај бр. 1230 од 20. 8. 1953. 
ског рата 1914-1918. године“. Одељење краља Александра I Карађорђевићаје потпуно уклоњено из музејске поставке док је „Одељење светског рата 1914-1918. године“ премештено у зграду II у којој је 8. јуна 1952. године била отворена поставка „Ратне историје народа Југославије“ у којој су били оригинални предмете, оружје, документа, фотографије, али и копије предмета од доласка Словена на Балканско полуострво па до завршетка Првог светског рата. ${ }^{21}$

Иако је највећи простор у поставци „Ратна историја народа Југославије“ одвојен је за презентацију Првог светског рата то је било веома мало за његов значај у односу на простор који су заузеле друге тематске целине и историјски догађаји. Изложен је велики број фотографија и различитог оружја и опреме зараћених страна. Водич Војног музеја текстом је пропратио узроке овог рата и најважније ратне операције у којима је учествовала српска војска и дао биографије српских војвода: Радомира Путника, Живојина Мишића, Степе Степановића и Петра Бојовића. Нигде у поставци и у водичу није било помена о краљу Петру, регенту Александру Карађорђевићу. ${ }^{22}$

По изласку из сале Првог светског рата, у једној мањој и завршној просторији посетиоце су сачекивали текстови оцена овог рата које су дали Владимир Иљић Лењин и Јосип Броз Тито.

Поводом расписивања конкурса за израду идејног пројекта зграде Војног музеја одржанои је и саветовање представника републичких министарстава просвете, на коме је разматрано питање оквирног тематског плана, на основу кога би се израдио експозициони

21 Водич Војног музеја ЈНА, Београд, 1953.

22 Водич Војног музеја ЈНА, Београд, 1953. 
план, да би се видело које су просторије потребне у новој музејској згради и каква би била њихова међусобна повезаност. Представници република и војске су након дводневног саветовања усвојили програм за израду идејних скица за зграду Војног музеја. Требало је да се изложбеном простору од $8050 \mathrm{~m} 2$ прикаже седам тематских целина од досељавања Словена на Балкан до краја Народноослободилачког рата 1945. године. За догађаје од 1903. до 1918. године (Балкански ратови 19121913. године и Велики рат 1914-1918) било је предвиђено $600 \mathrm{~m} 2$, док је за Народноослободилачки рат било предвиђено $4.000 \mathrm{~m} 2$, шест пута више. ${ }^{23}$

Пошто није грађена нова зграда него је за Војни музј адаптирана зграда Војногеографског института и у овој је стална поставка задржала исти однос у квадратури. НОР је у поставци добио 50\% простора као сва историја војске на простору Балкана од Римљана и доласка Словена на Балкан до 1941. године.

Непрекидан надзор над израдом тематског и експозиционог плана, над извођењем грађевинских, занатских и ликовних радова имала је Главна политичка управа ЈНА. Начелник те управе, генерал-пуковник Отмар Креачић звани Култура.

На дан ослобођења Београда, 20. октобра 1961. године, председник СФРЈ Јосип Броз Тито отворио је нову поставку.

После обиласка поставке Тито је рекао да није још средио утиске али да и поред тога сматра да је Војни музеј „добро организован, са тако темељитим приказивањем хисторијске борбе једног народа какав ја досада нисам видио“ указујући да оно што је приказано „још

23 Архива ВМ, Записник са конференције за корекцију и допуну програма за израду идејног пројекта зграде Војног музеја одржане 3. 7. 1950. 
није све, још ће се ту радити, а треба имати на уму и то да је Музеј преуређен и организован у једном кратком периоду“.

У погледу презентовања Другог светског рата на простору Југославије одао је признање Музеју који у поставци „посебно одражава, и то у пуној мјери, онај тешки посљедњи период наше хисторије, четворогодишњу епопеју наших народа“. Тито је био уверен да ће Војни музеј бити „један хисторијски момент, један споменик не само садашњој генерацији, која је много дала, него и читавој борби наших народа од њиховог доласка овамо па до данашњег дана“. 24

Стална музејска поставка, отворена октобра 1961. године, оцењивана је највишим оценама од људи из политике. Међутим, особеност времена у којем је настала, идеолошки наноси, административни језик, симетрија у презентовању прошлости југословенских народа, табу теме, неподобне и недодирљиве личности, „незгодни“ догађаји, историјски процеси супротни идеологији, „стратегија ћутања“ о геноциду над српским народом, модернизација прошлости, неравномерност у простору који су поједини догађаји добили у сталној поставци и друго, пресудно су утицали да изложени музејски материјал, ни у тренутку када је изложен јавности, није био у стању да поднесе озбиљнију критику струке и пресудно утиче на развијање историјске и друштвене свести. Уместо знања, преовлађивали су идеолошки садржаји. ${ }^{25}$

Код музејског презентовања Првог светског рата неки садржаји су сасвим изостављени: повлачење преко Албаније, геноцид над српским народом, операције црногорске војске и њихови сукоби са Аустријанцима,

24 Борба, 21. 10. 1961.

25 Предраг Лажетић, Војни музеј 1878-2014, Београд, 2014. стр. 287 
реорганизација српске војске на Крфу, Плава гробница - Видо, Солунски фронт, Топлички устанак, борбе за коначно ослобођење Србије, одбрана северозападних граница новостворене државе Краљевине СХС од Италије, Аустрије и Мађарске. Учињен је недопустив „пропуст" да се оба балканска рата и Први светски рат представе без иједне фотографије или уметничке слике краља Петра I Карађорђевића, регента Александра Карађорђевића, председника српске владе Николе Пашића и других истакнутих личности политичког и војног живота, који су били учесници догађаја. ${ }^{26}$

У тумачењу ратних догађаја и њихове политичке позадине видна су идеолошка тумачења, сасвим супротна знањима које данас, али је и онда поседовала српска и југословенска историографија. То је довело до неравномерности у представљању догађаја (на пример, простор који је дат добровољцима, прећуткивао се геноцид и ко га је извршио, пребацивала се кривица за страдање Срба на Аустријанце, Немце, Бугаре и потпуно изостављала недела Хрвата, Шиптара, муслимана и друго).

Приређивање изложби била је најзначајнија активност Војног музеја после отварања сталне музејске поставке која је односила велика материјална средства и на чијем је припремању трошено највише времена запослених у Музеју. Највећи број изложби био је са историјском тематиком и приређиван је поводом разних годишњица. Међу годишњицама које су обележаване преовладавале су оне са тематиком из НОР-a, живота и рада Јосипа Броза Тита и послератног развоја оружаних снага. Народноослободилачки рат и револуција, сматрани су најзначајнијим периодом у историји југословенских народа чије историјске поруке „се могу сагледати из њихових морално-етичких норми и вој-

26 Предраг Лажетић, Војни музеј 1878-2014, Београд, 2014. стр. 290 
них искустава“. Зато се у музеолошком приказу НОР-а инсистирало на томе да та искуства и поруке револуције, морају бити читљиве из сваке музејске изложбе.

Моралним вредностима и достигнућима револуције морала су да одишу сва музеолошка остварења са тематиком из НОР-а. Захтевано је да музејски радници који се баве овим историјским периодом морају полазити приликом реализације изложби од приказа руководеће улоге КПЈ, југословенског патриотизма широких народних маса, братства и јединства југословенских народа, хуманих особина бораца револуције и војних искустава НОР-а. Успешно музеолошко приказивање НОР-а зависило је од тога у којој су мери били заступљени сви ти елементи приликом израде идејне и тематско-експозиционе основе музејске изложбе. Сматрано је да без њих не може бити целовитог ни историјски објективног музеолошког приказа НОР-а и револуције, па ни великих могућности за васпитање младих генерација.

Прва изложба са тематиком из Првог светског рата реализована је у Војном музеју 1968. године. Почетком новембра 1968. године на основу одлуке политичке управе у Војном музеју направљен је за веома кратко време тематски план изложбе посвећене педесетогодишњици пробоја Солунског фронта 15-16. септембра 1918. године и стварању југословенске државе. Овакво изненадно интересовање Политичке управе за изложбу вероватно је било повезано са учешћем одреда JHA на паради савезничких армија која је требало да се одржи у Паризу 11. новембра 1968. године на педесету годишњицу завршетка Првог светског рата. ${ }^{27}$

Био је то први тематски план који је обрађивао период пре другог светског рата, а заједнички су га урадили пуковник др Петко Луковић, референт за „турски

27 Народна армија, бр. 1528 од 15. новембра 1968. 
период“ и XIX и XX век до краја Првог светског рата и капетан I класе Милорад Прелевић, референт за фабричко оружје и опрему. Изложба је била припремљена и отворена 7. децембра 1968. године али је, од аутора изложбе предложени наслов „Пробој Солунског фронта 15-16. септембра 1918. и стварање заједничке југословенске државе“, промењен у 'Борба наших народа за слободу 1914-1918”. Изложбу је у Београду видело видело око 20.000 посетилаца док ју је у 33 града у Србији видело током 1969. и 1970. године око 300.000 посетилаца. ${ }^{28}$

Поред изложби са тематиком из НОР-а и револуције, 1978. године поново је после десет година обележена годишњица пробоја Солунског фронта која је због заузетости изложбене сале Музеја организована у Дому JНА у Београду да би после тога била изложена у Културном центру на Новом Београду, Вождовцу и Бољевцима.

Изложбе са тематиком из Првог светског рата у већој мери него до тада су приређене осамдесетих година XX века. (Изложбе: 'Драгомир Глишић, ратни сликар 1914-1918", '70 година од Церске и Колубарске битке", "70 година од пробоја Солунског фронта и стварање Југославије”.

28 Изложба је после Београда била постављена у: Крагујевцу, Краљеву, Чачку, Титовом Ужицу, Горњем Милановцу, Шабцу, Ваљеву, Ћуприји, Пожаревцу, Смедереву, Зрењанину, Суботици, Новом Саду, Руми (1969. године) и у Нишу, Лесковцу, Врању, Гњилану, Призрену, Приштини, Косовској Митровици, Прокупљу, Пироту, Књажевцу, Бору, Зајечару, Крушевцу, Смедеревској Паланци, Врњачкој Бањи, Алексинцу, Трстенику, Жупском Александровцу и Младеновцу (1970. године). Архива Војног музеја, Извештај капетана I класе Милорада Прелевића бр. 1204/69 од 13, 1. 1970; Идрис Чејван, Рад Војног музеја у 1970. години, Весник бр. 17, Београд, 1971. стр. 237. 
Велику ангажованост у сарадњи са другим музејима и у стварању нових музеја и музејских поставки са тематиком из Првог светског рата показао је Милорад Прелевић. Свој ауторски потпис ставио је на музеје “Колубарска битка" у Лазаревцу (1984), 'Генерал Рудолф Мајснер” у Марибору (1986), “Војвода Живојин Мишић” у Струганику (1987) и “Церска битка” на Текеришу (1988).

У последњој деценији XX века и првој деценији XXI века војни музеј је организовао бројне изложбе са тематиком Првог светског рата или са предметима из тог великог ратног сукоба који су до тада били у музејском депоу и доступни само кустосима. У галерији војног музеја приређене су изложбе: „Старе заставе у збиркама Војног музеја“ „Одликовања Црне Горе, Србије и Југославије“, „Цер, Дрина, Колубара 1914“, „Сусрети српске и црногорске војске“, „Одбрана Београда 1915. године“, „Хладно оружје Србије, Црне Горе и Југославије 19. и 20. века“, „Руски уметници емигранти у Војном музеју“, „120 година Војног музеја“, „80 година пробоја Солунског фронта“, „Владари и војсковође у делима ликовних уметника из збирке Војног музеја“, „Ратни сликари, фотографи, аматери и дописници фотографи у Српској војсци 19141918“, „Занатско оружје Балкана од 17. до 19. века“, „Верски живот у војсци од Првог српског устанка до почетка Другог светског рата“, „Знамените личности у борби за ослобођење Србије и Црне Горе и њихови предмети из збирки Војног музеја“ и друге.

Војни музеј је 1993. године реализовао стару идеју о оснивању музеја који би сведочио о боравку српске војске на Крфу. Наиме тада је после акције прикупљања предмета коју је водио Војни музј и узраде тематског и експозиционог плана отворена у „Српској кући“ стална музејска поставка „Срби на Крфу 1916-1918.“. 
Са тематиком из Другог светског рата од деведесетих година до 2018. приређена је само једна изложба „У данима победе 1944/45. године“.

Велика друштвена криза у Југославији у другој половини шездесетих година доводи до тога да партија уместо пројеката за будућност наглашава поновно враћање традицији. На светлост дана извлачи се, 1968. године, датум оснивања Војног музеја 10. август (22. август по новом календару) 1878. године. За деведесетогодишњицу постојања Војни музеј је указом председника СФРЈ Јосипа Броза Тита одликован Орденом за војне заслуге са великом звездом.

Када је 1978. године постављено питање евентуалног обележавања стогодишњице Војног музеја, решено је „након консултације правних и других органа у ЈНА да у постојању данашњег Војног музеја као Музеја JHA, као уосталом и са другим државним и друштвеним институцијама бивше Југославије (а поготово кнежевине Србије из 19. века) не постоји никакав правни континуитет“. На основу тога је решено да се не обележава 100-годишњица већ да треба обележавати неку од важних послератних година из историје ове институције.

Политичка управа одлучила је да се као дан Војног музеја одреди датум ослобођења Београда, 20. октобар 1944. године. Месец дана касније колектив Војног музеја обележио је „35-годишњицу свог оснивања и рада у новој социјалистичкој Југославији“.29

За ту новоустановљену годишњицу Војни музеј био је Указом председника СФРЈ, бр. 118 од 12. октобра 1979. године, одликован Орденом братства и јединства са златним венцем.

29 Ернест Мезга, Тридесетпет година рада Војног музеја, Весник, бр. 23-26, Београд, 1980. стр. 7. 
Истичући вредности садашње музејске поставке, начелник музеја сматрао је потпуно природним што је у њој „готово половина простора посвећена НОР-у и социјалистичкој револуцији“ и што је „целокупна војна историја југословенских народа до 1941. године приказана на релативно малом простору“. Као највећи квалитет сталне изложбене поставке у целини истакао је да је у њој дат „објективан, марксистички приказ целокупног историјског развоја“.

Ни пет година касније ништа се није променило у датуму обележавања дана Војног музеја. Задржана је, чак и појачана мисао да прави рад музеја почиње тек после ослобођења Београда, октобра 1944. године. Изложбе приређиване у Војном музеју и чланци објављивани у часопису Весник углавном су обрађивали предмете, догађаје и личности из НОР-а и социјалистичке револуције.

Прави се још већа разлика у оцењивању вредности предмета изложених у сталној поставци и похрањених у музејским збиркама. Као предмети који „представљају национално благо непроцењиве вредности“ набрајају се предмети из НОР-а и револуције, док се као „јединствени“ оцењују предмети који потичу из Збирке наоружања и војне опреме српске војске из балканских ратова и Првог светског рата. ${ }^{30}$

Игра са датумима, годишњицама, прекрајањима времена трајања институције резултирали су губитком памћења о трајању Војног музеја и његовој вредности. Револуционарно убеђење да „све почиње од нас“ довело је до тога да су виле из устанка 1941. године вредније од предмета војвода из Првог и Другог српског

30 Бранка Милосављевић, Четрдесет година рада Војног музеја, Весник, бр. 30, Београд, 1984. стр. 125. 
устанка или предмета из Првог светског рата. Читаве епохе остају ван памћења, а хиљаде музејских предмета потискују у други план и осуђују на трајан боравак у музејским депоима, далеко од очију јавности. Четврт века музеј је био у трагању за својим идентитетом, у коме је идеолошко слепило надјачало струку и стручну процену вредности музејских предмета и важности историјских догађаја.

Промене до којих је дошло у свету и Југославији крајем осамдесетих и почетком деведесетих година нису оставиле ни Војни музеј и запослене у њему на дотадашњим схватањима о традицији и оценама вредности музејских збирки и предмета.

До враћања традицији у обележавању годишњице Војног музеја на дан његовог оснивања 1878. године поново се долази 1993. године, у време када је увелико дошло до сецесије Словеније, Хрватске и Босне и Херцеговине из СФРЈ, када је на просторима Хрватске и БиХ беснео грађански рат и после стварања Савезне Републике Југославије. У листу Војска објављен је, априла 1993. године, специјални додатак поводом 115 - годишњице Војног музеја, у коме су чланови колектива музеја дали своје прилоге. Аутор чланка "Музејски драгуљи”, који је приказао највредније предмете из фондова Војног музеја уместо предмета из НОР-а и социјалистичке револуције (вила и копаља из устанка 1941. године, предмета са Неретве и Сутјеске, застава партизанских јединица, предмета Јосипа Броза, Моше Пијаде, Владимира Бакарића и другог) сада је истицала музејске предмете из Првог и Другог српског устанка, балканских ратова и Првог светског рата. Поново су почеле да се "вијоре" заставе из Првог и Другог српског устанка, а предмети устаничких првака постали су најзначајнији. Као веома значајне издвајају се заставе српских пукова, предмети српских војвода, лично на- 
оружање генерала Михаила Живковића, Милоша Васића, Павла Јуришића Штурма. Истицани су предмети занатске израде и предмети Карађорђевића који су до тада помињани само у негативном контексту. ${ }^{31}$

\section{Извори и литература:}

Необјављени извори

- Архив Војног музеја

- Архив Србије (фондови: Министарство просвете и вера; Главне контроле; Недићев фонд)

- Архив ВИИ (фондови: Пописник 1-17; фонд Војске Краљевине Југославије; Недићев фонд; Немачки фонд; фонд НОР-а; фонд Драже михаиловића, Персонална документа).

- Архив Југославије (фондови: Државне комисије за утврђивање ратне штете; Фонд-54 Репарациона комисија владе ДФЈ, фонд Двора Краљевине Југославије; Централни Пресбиро председништва министарског савета 1929-1941).

-Архив града Београда, Збирка архивалија ЗАРХ К-9/1ф ЖП, 1;

Извори:

- Службени војни лист 1917-1940;1945-1999

- Државни календар Краљевине СХС (Краљевине Југославије)

Штампа

- Српске новине

- Београдске општинске новине

- Војска

- Народна армија

- Фронт

- Борба

- Политика

31 Бранка Милосављевић, Највреднији предмети, музејски драгульи, Војска бр. 45, од 1. априла 1993. стр. 18. 
Часописи

- Весник Војног музеја

- Војноисторијски гласник

- Ратник

- Годишњак Српске кратьевске академије

- Наслеђе

- Обнова

- Музеји

- Годишюак града Београда

\section{Литература}

- Агонија Београда у светском рату, Београд, 1931.

- Андрејевић Кун Н., Задаци музеја у новим друштвеним условима у нашој земљи, Музеји, 1, Београд, 1948.

- Београд у рату и револуиији 1941-1945, I-II, Београд, 1984.

- Београдски музеји, Годишњак Музеја града Београда, I, Београд, 1954.

- Бјелајац Миле, Војска Кралевине Срба, Хрвата и Словенаиа - Југославије 1922-1935, Београд, 1994.

- Бјелајац Миле, Војска Кральевине Срба, Хрвата и Словенаиа 1918-1921, Београд, 1988.

- Водич Војног музеја, Београд, 1953.

- Водич, Војни музеј Београд, Београд, 1984.

- Војна енииклопедија, књига 8, Београд, 1974.

- Вујовић Бранко, Улога руских уметника у развоју тиковне културе у Србији, Руска емиграција у српској култури ХХ века, зборник радова, том II, Београд, 1994.

- Вуковић Војислав, Војни музеј, Велики војни календар 1936.

- Дабић Љубица, Руски уметници емигранти у Војном музеју, Каталог изложбе, Београд, 1996.

- Дарови Војном музеју, каталог изложбе Војног музеја, концепција каталога и редакција Драгана Самарџић, Београд, 1990.

- Димић Љубодраг, Агитпроп култура. Агитпроповска фаза културне политике у Србији 1945-1952, Београд 1988.

- Димић Љубодраг, Културна политика у кралевини Југославији 1918-1941, I-III, Београд, 1996. 
- Димић Љубодраг, Историографија и идеологија - југословенско искуство 1945-1955, Годишњак за друштвену историју, година I, свеска I, Београд, 1994.

- Димић Љубодраг, Рат и историограбија, Краљево октобра 1941, Краљево, 2003.

- Драганић С., Изложба НОБ у Војном музеју ЈНА, Музејски весник, бр. 1, Београд, јануар-фебруар 1951.

- Ђурић Војислав, Улога музеја и музејских радника у нашој земљи, Музеји, 2, Београд 1949.

- Изложба НОБ, каталог изложбе, Београд, 1951.

- Живуловић Жика, Преци и потомии, Београд, 1998.

-Живковић Никола, Ратна штета коју је Немачка учинила Југоставији у Другом светском рату, Београд, 1975.

- Зековић Марина, Ратни сликари, фотографи аматери и дописници фотограби у српској војсии 1914-1918, Каталог изложбе Војног музеја, Београд, 2001.

- Јовановић Ј., Српска изложба у Лондону 1907. године, Београд, 1908.

- Јовановић Ж., Из старог Београда, Београд, 1964.

- Јовановић Мирослав, Руска емиграција на Балкану (19201940), Београд, 2006.

- Кресо Мухарем, Немачка окуачиона управа у Београду 1941-1944, Београд, 1979.

- Кресо Мухарем, Услови живота и рада у окупираном Београду, Војноисторијски гласник, бр. 3, Београд, 1972.

- Лажетић Предраг, Предмети династије Петровић-Његош y Војном музеју у Београду, Историјски записи, година LXXV, 6p. 3-4, Подгорица, 2002.

- Лажетић Предраг, Војни музеј 1878-2014, Београд, 2014.

- Мезга Ернест, Политички рад у ЈНА, Београд, 1988.

- Петрановић Бранко, Историја Југославије 1918-1988, I-III, Београд, 1988.

- Петрановић Бранко, Југославија на размеђу (1945-1950), Подгорица, 1998.

- Петрановић Бранко, Обнова у Београду 1944-1945, Годишњак града Београда књ. XVII, Београд, 1970.

- Петровић Ђурђица, Делатност Војног музеја ЈНА у оквиру акиије Исток-Запад, Музеји, бр.14, Београд, 1962. 
- Пилчевић Ђорђе, Академски сликар Михаило Миловановић, живот и дело 1879-1941, Ужице, 1998.

- Пилетић Д., Осврт на изложбе и предавана Војног музеја ЈНА у току 1954. године, Весник, 2, Београд, 1955.

- Прибаковић Душан, Војни музеј ЈНА, Годишњак музеја града Београда, књ. I, Београд, 1954.

- Приручник за војно-политичку обуку борача Југословенске армије, I-II, Београд, 1946-1947.

- Радовић Анђелија, Знамените тичности у борби за ослобођеюе Србије и Црне Горе и юихови предмети у збирки Војног музеја, каталог, Београд, 2005.

- Самарџић Драгана, Војне заставе Срба до 1918., Београд, 1983.

- Самарџић Драгана, Старе заставе у Војном музеју, каталог изложбе и збирке, Београд, 1993.

-Свечано отваране Војног музеја, Београдске општинске новине, Београд, 1937.

- Станковић Ђорђе, Димић Љубодраг, Историографија под надзором, Прилози историје историограбије, I, Београд, 1996.

- Чејван Идрис, Деведесет година Војног музеја, Београд, 1968.

- Четрнест векова борби за слободу, Београд, 1968.

- Шуица Нада, Каталог уметничке збирке, Дела 1912-1918, из Војног музеја у Београду, Београд, 1982. 